\title{
DOES RELIGIOSITY MATTER IN THE ERA OF INDUSTRIAL REVOLUTION 4.0?
}

\author{
Ahmad Amri Zainal Adnan*, Nek Kamal Yeop Yunus, \\ and Arsalan Mujahid Ghouri \\ Department of Business Management and Entrepreneurship, \\ Sultan Idris Education University, 35900 Tanjung Malim, Perak, Malaysia \\ *Corresponding author: a.amri@fpe.upsi.edu.my
}

Published online: 25 October 2019

To cite this article: Adnan, A.A.Z., Yunus, N.K.Y., and Ghouri, A.M. (2019). Does religiosity matter in the era of Industrial Revolution 4.0? Asian Academy of Management Journal, 24(Supp. 2), 67-77. https://doi.org/10.21315/aamj2019.24.s2.5

To link to this article: https://doi.org/10.21315/aamj2019.24.s2.5

\begin{abstract}
Since the hype of Industrial Revolution 4.0 that was brought up by Klaus Schwab in 2016, once again the question of values and beliefs becomes a debate. If religiosity is sidelined in our efforts to automate services and let machines do the jobs of human, then human will truly be substituted by artificial intelligence (AI). Does religiosity matter and can it play a role in the new industry revolution? This study will explore the impact of religiosity towards Muslim officers' work behaviour in the higher learning institutions in Malaysia. Through in-depth interviews and thematic analysis, this study found that religiosity has an impact on the respondents' work behaviour to a certain degree. Five themes emerged from the thematic analysis: religiosity, personality, competency, environment, and leadership. Besides religiosity, factors such as attitude, leadership, and environment also play a vital role in the enhancement of a religious-based organisational culture.
\end{abstract}

Keywords: Muslim work behaviour, religiosity, Industrial Revolution, IR 4.0, leadership

\section{INTRODUCTION}

Study on the Fourth Industrial Revolution or IR 4.0 is gaining attention from both academic and industrial sectors. Without a doubt, technology is and will still be the driving force of industry and economy. Abdullah, Abdullah and Salleh (2017) described that the internet of things (IoT), connectivity, artificial intelligence, and

(C) Asian Academy of Management and Penerbit Universiti Sains Malaysia, 2019. This work is licensed under the terms of the Creative Commons Attribution (CC BY) (http://creativecommons. org/licenses/by/4.0/). 
breakthrough technologies built around our lives will affect the society in ways that we cannot fully describe and anticipate. This is true considering the fast pace of technology advancement nowadays.

Recently, the Malaysian Minister of Education launched the ministry's theme for 2018, which is "Higher Education 4.0: Knowledge, Industry, and Humanity." The ministry stressed that technology is merely a tool to aid human needs. Managing technology is part of human responsibility and human who loses his humanity can't manage technology for the benefit of the society. In other words, we must have high-tech and at the same time "high-touch."

Schwab (2016) in his book, The Fourth Industrial Revolution, stresses that we need to understand the impacts of technology that is advancing at a very rapid pace and how it changes our lives in shaping the future generation. Schwab suggests that we manage this phenomenon (IR 4.0) by implementing four types of intelligence (contextual, emotional, spiritual, and physical) to ensure that the future is shaped without excluding values and humanity. He emphasises that values and humanity is vital in managing change that is driven by technology. Values and humanity can bring meaning and a sense of purpose to organisations.

Similarly, the need for meaning and higher purpose brought religion and faith into the world of business (Kouzes \& Posner, 2012). The manifestation of religious beliefs can benefit individual, and so the effects should be the same when it is manifested throughout an organisation, as the organisation culture. This study aims at exploring the impact of religiosity towards Muslim work behaviour in the higher education setting. In particular, it addresses two research questions:

1. How far does religiosity influence work behaviour?

2. Do religious values have significant effect on the organisation?

Drawing on data generated from 14 semi-structured interviews with middle-ranked professionals in the higher learning institutions, the study responds to Schwab's (2016) suggestion that values and humanity are included in paving the Fourth Industrial Revolution by bridging religiosity's role in work behaviour.

\section{LITERATURE REVIEW}

The degree to which an individual is a religious person and the way those beliefs are manifested can be concluded as religiosity (Vitell et al., 2008). Various components or dimensions of religiosity have been identified by researchers in 
the field of religiosity. Faulkner and De Jong (1966) in their study found five dimensions of religiosity, namely ideological, ritualistic, experiential, intellectual (knowledge), and consequential (religious impression on non-religious life). De Jong, Faulkner and Warland (1976) identify six dimensions of religiosity: beliefs, experiences, religious charities, religious knowledge, individual moral consequences, and social consequences.

Previous studies showed that the number of dimensions or constructs of religiosity is diverse. Muhammad Syukri Salleh (2012) conclude that the dimensions and components of religiosity developed by previous researchers can be categorised into four main points, namely belief, knowledge, practice, and experience. Saroglou (2011) admits the differences in religious dimensions exist across religious alliances, but the universal dimension of religiosity is the belief in external transcendence.

Religious concepts from Islamic perspective have been described through the model of Muslim Religiosity developed by Azimi Hamzah et al. (2007), which consists of two elements, namely the Islamic worldview and Muslim personality. Azimi et al. (2007) develop the concept of Muslim religiosity through three basic dimensions: Islam, iman (faith) and ihsan (courtesy). A study by Raida Abu Bakar, Fang Lee Cooke and Nuttawuth Muenjohn (2016) found that Islamic religiosity seems to be evident in the moral reasoning and the management of behaviour at the workplace.

Religion engenders the shape of behaviour, which is strongly followed by people (Ghouri, Khan \& Kareem, 2016; Ghouri et al., 2018). Previous studies that involved religiosity and work behaviour found significant relationship between the two variables (Weaver \& Agle, 2002; Emmons \& Paloutzian, 2003; Gibson 2005; Pargament, Magyar-Russell \& Murray-Swank, 2005; Sikorska-Simmons, 2005; Ahmad Amri et al., 2017). The connection between religion and work was found throughout all religious traditions (Garvey, 2003).

Omar (1996) suggested that individuals who give in to faith will be more open minded, see the organisation as a part of a bigger system, and the end goal is to seek God's pleasure. Empirical studies indicate that countries with a higher percentage of religious individuals generally outperform the economic success of those countries with smaller percentage of religious groups (Galbraith \& Galbraith, 2007).

With the Fourth Industrial Revolution coming our way, religiosity might be the element that can balance humanity and insanity as Sav (2016) suggested that 
religiosity can be an important factor for work-life balance. Contrary to believes and findings, the association between religiosity and organisational outcomes has been ignored in mainstream Human Resource Management (HRM) research (Mellahi \& Budhwar, 2010).

Raida Abu Bakar et al. (2016) also stated that existing studies on religiosity and HRM have argued the role of religiosity in influencing people's work behaviour. This could be a sign that management did not perceive religiosity as an important contributor to work behaviours and organisational outcomes especially when it comes to future agendas. Hence, we propose that religiosity influence and affect work behaviour, and thus the performance of organisations.

\section{METHODOLOGY}

This study was carried out using administration officers from five public universities in Malaysia as its respondents. The higher learning institutes were chosen which comprise a comprehensive, two research, and two focused universities. A purposive sampling method was used. A number of 14 Muslim respondents were chosen using snow-balling technique to acquire a more precise data on the topic. From this number, $35.7 \%$ are males and $64.3 \%$ are females. Most of the respondents are in the age group of 30-35 years old (34.2\%), followed by 36-40 years old (20.2\%). Also, out of these respondents, $57 \%$ are in middle-management positions and $43 \%$ are in top management. From the number, 11 have been working for more than 10 years. Data were obtained through an in-depth interview. Each respondent was given semi-structured questions. Thematic analysis was used to identify themes and concepts, and also the relationship between the concepts.

\section{RESULTS}

The thematic analysis done found 31 concepts that are relevant to the study. All concepts can be categorised into five main categories of theme based on their similarities. Systematic coding came up with these results:

1. First-stage coding - 31 concepts emerged based on the research questions.

2. Second-stage coding - The concepts fit into five categories: religiosity, competency, environment, personality, and leadership. The following table summarises how the 31 concepts fit into the five categories: 
Table 1

Summary of second-stage coding

\begin{tabular}{lllll}
\hline Religiosity & Competency & Environment & Personality & Leadership \\
\hline Intention & Competency & Environment & Character & Leader \\
Awareness & Background & Culture & Attitude & Encouragement \\
Purpose & Knowledge & Competition & Responsibility & Appreciation \\
Obedience & Education & Motivation & Trustworthy & Satisfaction \\
Worship & Efficient & Peers & Grateful & Enforcement \\
Tremble & Professional & Teams & Integrity & \\
Understanding & & & Sincere & \\
\hline
\end{tabular}

3. Third-stage coding - The third stage of coding found these connections between the five main categories; there are two contrasting views about the factors that impact work behaviours. On one side, respondents are in the view that intrinsic factors such as religiosity and attitude are the most important aspect to enhance positive work behaviours. When asked for the reason the performances of the officers (Muslim) in the public sector were not excellent (Question: Why is the performance of the officers in the public sector not excellent?), one of the respondents mentioned the following:

To me, if you are given courses in integrity, but it's not on your own desire to go, to practice integrity, it's very hard. (IN1)

Religiosity was also mentioned as a motivator:

Religion does not affect behaviour, but how much we submit to it that counts. (IN1)

The concept of work as a worship or ibadah also contributes to success, but it is still not fully understood based on the responses:

... the understanding about the concept of work as an ibadah is not heavily stressed, and just a few people understand the concept of work as an ibadah. (IN5)

One more thing that I notice, an employee may be OK in terms of interpersonal communication but in terms of work, he does not feel as if it is a responsibility to finish it on time, he does not feel guilty to take a leave. I feel that he does not feel that work as part of ibadah. (IN7) 
On the other hand, some of the respondents stressed that extrinsic factors such as environment, culture and leadership as prominent factors that affect employees' work behaviour. One of the respondents said:

The environment (in the public sector) tends to turn us to be not devoted workers in the public sector. (IN7)

This statement was supported by other respondents:

To me, actually it's more to the culture. The culture that has been rooted in the administration system. I mean, when we talk about the government sector, it is related to the culture that has been instilled there. The earlier generation created the culture and was inherited by the newer generation. (IN5)

The immediate supervisor, environment and sometimes the head of department really support their subordinates. (IN10)

The second connection that was found from the analysis is that religiosity specifically affects work behaviour. When asked how far religiosity affects their work behaviour (Question: How far does religiosity affect your work behaviour?), $64 \%$ of the respondents agreed that religiosity affects work behaviour. One of them said:

Religiosity is an important factor that contributes to the excellence of oneself... if we work because of the KPIs, because the organisation's goals, we have to associate it with what I said earlier, we have to have the ultimate goal which is sincerely for Allah...(IN13)

The respondents also relate religiosity with integrity and trustworthiness. They said:

If they have a deep understanding towards the religion, obedience and integrity will be even more obvious. Moreover, when it involves issues on financial and integrity. I think religion is an important factor. (IN4)

The value of integrity and trustworthiness arises from the understanding of the religion as mentioned by the respondents:

A person will feel embarrassed with God if he does not embrace the teaching of the religion. (IN1) 
When we realise about the punishments and rewards, we will do our best, not just in our lifetime because it will affect us in the hereafter. (IN6)

The responses infer that comprehension and obedience towards religion, particularly on the concept of work as a part of ibadah, can develop virtues such as integrity, responsible and sincerity in the organisation. Nonetheless, religion per se without submission won't be the determining factor of excellence.

The third finding is that the effectiveness of work values based on religion still relies on one's own attitude, albeit the organisation's effort to promote the values among employees. The feedbacks from the respondents posit this statement when they were asked to elaborate the effectiveness of work values in their organisations (Question: Do religious work values in your organisation have a significant effect on the organisation?):

Like I said earlier, it depends on the attitude of the employee, the trustworthiness and responsibility in executing his job. On the side of the employers, I think they have done all sort of efforts, but it depends on the employees to adapt those things. (IN6)

The organisation here opens many opportunities for the staff to embrace the values, but it is up to them whether to grab it or not. (IN9)

If they are used to it, they will automatically do it. To me, the organisation has given the goals and means to achieve those goals. But it depends on the individuals to embrace, and relate it to their lives. (IN10)

Whatever the course is to instil values or integrity, you want to take it or leave it, it still depends on the individual. (IN2)

Besides the individual's will to change, another prominent factor is the enforcement of the values. These statements are strengthened by other respondents:

Sometimes we can see that what is lacking is enforcement. (IN8)

To me, the university that I work for does instil the values but I feel that it needs enforcement. (IN1) 
These three connections give us some insights that religiosity is still relevant even in the age of technology, and supported the findings of Yousef $(2000 ; 2001)$ that religiosity, particularly Islamic work ethics, influences organisation outcomes such as employees' job satisfaction and commitment.

\section{DISCUSSION}

The effectiveness of religiosity in shaping work behaviour in an organisation depends on intrinsic and extrinsic factors. Myer (2013) also agrees that these two factors affect behaviour. Thus, individuals need to know, understand, and submit to the fundamental of the religion to ensure that it can be manifested in their work behaviour, besides the enforcement by employers.

The overall outcome of the analysis concludes that the majority of respondents (64\%) agreed that religiosity has an impact towards work behaviour. The effectiveness of religiosity as a factor to work behaviour depends on the individual, work environment, and leadership in the organisation. At individual level, consciousness, comprehension, and submission to the religion's teaching are critical. In addition, enforcement and leadership are the external factors.

The findings are in line with Parboteeah, Hoegl and Cullen's (2009) findings that suggest religion and religious environment are positively correlated with work commitment and also act as an important driver towards work engagement (Raida Abu Bakar et al., 2016). The findings are also parallel with those of Yaacob (2015). He suggested three factors that will have big impact on attitude, which are religious consideration, personal relation, and bureaucratic tendency.

According to Brotheridge and Lee (2007), a sense of purpose in work is the key to why employees choose to behave constructively. This explains why the respondents stressed on the submission to religion and the comprehension towards the concept of work as an ibadah in order to gain excellence at the workplace.

In terms of environment, Parboteeah, Hoegl and Cullen (2009) suggested that a conducive religious environment influence people to perceive work as a responsibility. Thus, employers need to take the initiatives to inculcate a culture that is based on religiosity. The effectiveness in implementing these initiatives depend on individuals and also leadership in the organisation. Despite all this, religiosity should only be considered as one of the crucial factors in predicting work behaviour, and not the most important factor, as there are many more factors that also influence work behaviour. 


\section{CONCLUSION}

This study suggests that although religiosity is not the main factor that enhances the performance of employees, it still has an impact on work behaviour. Employers need to bear in mind that in the age of industrial revolution, humans are still connected with their values and beliefs, thus religiosity is essential to provide a sense of meaning in work. The results of this study have implications for potential positive social change on the individual level and organisational level. At the individual level, the results of this study gave an insight of how far religiosity can impact individual performance. At the organisational level, the results of this study have implications for positive organisational change by improving human resource practices and it should raise an awareness of the importance of religiosity to employees' work-life balance.

\section{REFERENCES}

Abdullah, D., Abdullah, M.Y., \& Salleh, M.A.M. (2017). A review on the concept of fourth industrial revolution and the government's initiatives to promote it among youths in Malaysia. E-Bangi Journal of Social Sciences and Humanities, 1-8.

Ahmad Amri, Z.A., Mastor, K.A., Kasan, H., \& Hamzah, F.M. (2017). Religiositi sebagai faktor mediasi tingkah laku kerja Muslim. Jurnal Hadhari, 9(1), 141-156.

Azimi Hamzah, Krauss, S.E., Sidek Mohd. Noah, Turiman Suandi, Ramaya Juhari, Jamiah Manap, Khairul Anwar Mastor, Azma Mahmoud, \& Hasnan Kassan (2007). Muslim religiosity and personality assessment: Prototype for nation building. Serdang: Institute for Social Science Studies.

Brotheridge, C.M., \& Lee, R.T. (2007). Hands to work, heart to God: Religiosity and organizational behavior. Journal of Management, Spirituality \& Religion, 4(3), 287-309. https://doi.org/10.1080/14766080709518666

De Jong, G.F., Faulkner, J.E., \& Warland, R.H. (1976). Dimensions of religiosity reconsidered: Evidence from a cross-cultural study. Social Forces, 54, 866-889. https://doi.org/10.2307/2576180

Emmons, R.A., \& Paloutzian, R.F. (2003). The psychology of religion. Annual Review of Psychology, 54, 377-402. https://doi.org/10.1146/annurev. psych.54.101601.145024

Faulkner, J.E., \& De Jong, G.F. (1966). Religiosity in 5-D: An empirical analysis. Social Forces, 45, 246-254. https://doi.org/10.2307/2574395

Galbraith, C.S., \& Galbraith, D.M. (2007). An empirical note on entrepreneurial activity, intrinsic religiosity and economic growth. Journal of Enterprising Communities: People and Places in the Global Economy, 1(2), 188-201. https://doi. org/10.1108/17506200710752601

Garvey, G. (2003). The theory of the firm, managerial responsibility, and catholic social teaching. Journal of Markets and Morality, 6(2), 525-540. 
Ghouri, A.M., Khan, N.R., \& Kareem, O.A. (2016). Improving employees behavior through extension in theory of planned behavior: A theoretical perspective for SMEs. International Journal of Business and Management, 11(11), 196-213. https://doi.org/10.5539/ijbm.v11n11p196

Ghouri, A.M., Khan, N.R., Kareem, O.A., \& Shahbaz, M. (2018). Religiosity effects on employees in SMEs: An Islamic country perspective. Journal of Enterprising Culture, 26(1), 1-27. https://doi.org/10.1142/S0218495818500048

Gibson, D. (2005). Spirituality in America: God on the job? Ladies Home Journal. Retrieved 15 February 2017 from http://www.dgibson.com/site/pdfs/GOD_JOB. pdf.

Kouzes, J.M., \& Posner, B.Z. (2012). The leadership challenge (5th ed.). San Francisco: John Wiley \& Sons.

Mellahi, K., \& Budhwar, P.S. (2010). Introduction: Islam and human resource management. Personnel Review, 39, 685-691. https://doi.org/10.1108/00483481011075558

Muhammad Syukri Salleh. (2012). Religiosity in development: A theoretical construct of an Islamic-based development. International Journal for Humanities and Social Science, 2(14), 266-274.

Myers, D.G. (2013). Social psychology (11th ed.). New York: McGraw-Hill.

Omar, W.L.O.W. (1996). Pengurusan Islam abad ke-21: Revolusi pengurusan untuk keunggulan sektor awam dan korporat. Kuala Lumpur: Utusan Publications \& Distributors.

Parboteeah, K.P., Hoegl, M., \& Cullen, J.B. (2009). Religious dimensions and work obligation: A country institutional profile model. Human Relations, 62(1), 119148. https://doi.org/10.1177/0018726708099515

Pargament, K.I., Magyar-Russell, G.M., \& Murray-Swank, N.A. (2005). The sacred and the search for significance: Religion as a unique process. Journal of Social Issues, 64, 665-687. https://doi.org/10.1111/j.1540-4560.2005.00426.x

Raida Abu Bakar, Fang Lee Cooke, \& Nuttawuth Muenjohn. (2016). Religiosity as a source of influence on work engagement: A study of the Malaysian finance industry. The International Journal of Human Resource Management, 29(18), 2632-2658. https://doi.org/10.1080/09585192.2016.1254103.

Saroglou, V. (2011). Believing, bonding, behaving, and belonging: The big four religious dimensions and cultural variation. Journal of Cross-Cultural Psychology, 42, 1320-1340. https://doi.org/10.1177/0022022111412267

Sav, A. (2016). The role of religion in work-life interface. The International Journal of Human Resource Management, 1-22. https://doi.org/10.1080/09585192.2016.1 255905

Schwab, K.M. (2016). The Fourth Industrial Revolution. Geneva: World Economic Forum.

Sikorska-Simmons, S. (2005). Religiosity and work-related attitudes among paraprofessional and professional staff in assisted living. Journal of Religion, Spirituality and Aging, 18(1), 65-82. https://doi.org/10.1300/J496v18n01_05

Vitell, S.J., Bing, M.N., Davidson, H.K., Ammeter, A.P., Garner, B.L., \& Novicevic, M.M. (2008). Religiosity and moral identity: The mediating role of self-control. Journal of Business Ethics, 88, 601-613. https://doi.org/10.1007/s10551-008-9980-0 
Weaver, G.R., \& Agle, B. R. (2002). Religiosity and ethical behavior in organizations: A symbolic interactionist perspective. The Academy of Management Review, 27(1), 77-97. https://doi.org/10.5465/amr.2002.5922390

Yaacob, H.F. (2015). Human capital and human resource development in Islamic perspective. Proceeding of International Conference on Human Resource Development, 429-438.

Yousef, D.A. (2000). Organizational commitment as a mediator of the relationship between Islamic work ethic and attitudes toward organizational change. Human Relation, 53(4), 513-537. https://doi.org/10.1177/0018726700534003

Yousef, D.A. (2001). Islamic work ethic - A moderator between organizational commitment and job satisfaction in a cross-cultural context. Personnel Review, 30(2), 152-169. https://doi.org/10.1108/00483480110380325 